\title{
Barriers and opportunities for adapting to climate change on the North Coast of São Paulo, Brazil
}

\author{
Eliane Simões $^{1}$ - Wilson C. de Sousa Junior ${ }^{1}$ - Débora M. de Freitas ${ }^{1,2}$. \\ Morena Mills $^{3}$ - Allan Y. Iwama ${ }^{1}$ - Isabel Gonçalves ${ }^{1} \cdot$ Débora Olivato $^{1}$. \\ Pedro Fidelman ${ }^{4}$
}

Received: 25 January 2016/Accepted: 20 February 2017/Published online: 14 March 2017

(c) Springer-Verlag Berlin Heidelberg 2017

\begin{abstract}
This paper examines barriers and opportunities for climate change adaptation in an urban coastal setting where adaptation is in its infancy. It draws on a diagnostic framework as a foundation for identifying and organising barriers and opportunities in terms of three broad phases of the adaptation process, i.e. (1) understanding the problem, (2) planning adaptation options and (3) managing implementation of such options. Data come from the analysis of documents (e.g. policy, plans and reports) and a survey of 49 representatives from 42 organisations (e.g. government, environmental non-governmental organisations, businesses and local industry and professional associations). Nineteen barriers and/or opportunities pertaining to the different phases of the adaptation process were identified. Three of those barriers (i.e. competing priorities, existing
\end{abstract}

\section{Editor: James Ford.}

Electronic supplementary material The online version of this article (doi:10.1007/s10113-017-1133-5) contains supplementary material, which is available to authorized users.

Eliane Simões

simoeslica@gmail.com

1 Department of Water Resources and Environment, Aeronautics Institute of Technology, Pça. Mal. Eduardo Gomes, 50 CTA/IEI, São José dos Campos, SP CEP 12228-900, Brazil

2 Biosciences Institute, São Paulo State University-UNESP, Coastal Campus, Praça Infante Dom Henrique $s / n$, P.O. Box 73601, São Vicente, SP, Brazil

3 Department of Life Sciences, Imperial College London, Silwood Park Campus, Buckhurst Road, Ascot, Berkshire SL5 7PY, UK

4 Sustainability Research Centre, University of the Sunshine Coast, Sippy Downs, QLD 4556, Australia management context and existing ecological context) are our additions to the initial list of common barriers proposed in the diagnostic framework. Barriers pertaining to the understanding phase were the most frequently noted by respondents. The understanding phase was also one which most of the barriers were nevertheless considered as opportunities. Emerging critical barriers and/or opportunities for climate change adaptation included perception of signal, availability and accessibility of information, existing management context and leadership. We propose that addressing these barriers and opportunities would involve improving perception about climate change and availability and accessibility of information, fostering anticipatory planned adaptation through the existing management context and developing leadership for adaptation. Findings from this study may prove useful to other jurisdictions, particularly those where climate adaptation is at its early stages of development.

Keywords Adaptation - Barriers and opportunities . Climate change $\cdot$ Brazil

\section{Introduction}

Challenges facing the future of the world's urban areas, particularly those located on the coast, are enormous, diverse and complex. Home to the majority of the world's population, the coastal zone is the focus of development, competing interests and growing concern due to climate change impacts (Dutra et al. 2015; Gibbs 2015; Sales 2009; Small and Nicholls 2003). Rising sea levels (Burrows et al. 2011; Cooper and Pile 2014; Gibbs 2015; Measham et al. 2011), changes in rainfall patterns, flooding and coastal erosion pose major climate-related threats to environmental 
processes and private and public assets located in vulnerable areas (Adger 2003; Bradley et al. 2015; Gibbs 2015). The poorest and marginalized populations are the ones most harshly affected by such threats (Taylor et al. 2012; Sales 2009). Cities and their citizens need to be strategic to better prepare for climate-related events that will affect them. In this context, adaptation emerges as an important societal response to the risks and impacts of climate change (Fidelman et al. 2013).

Adaptation encompasses numerous actions addressing impacts directly (e.g. loss of biodiversity) (Adger 2003) and/or indirectly (e.g. by increasing social-ecological resilience). These include, for example, using scarce water more efficiently, adapting existing building codes to stand future climate conditions and extreme weather events and developing spatial plans and corridors to help species migration (European Commission 2007). Central to the concept of adaptation is the reduction in harm and/ or realisation of benefits to humans (Cooper and Pile 2014) and human adjustments to resource availability and risk at different spatial and societal scales (Adger et al. 2005). For the purposes of this paper, we use a generic but inclusive conceptualisation of adaptation, as proposed by Moser and Ekstrom (2010, p. 22026), i.e. adaptation "involves changes in social-ecological systems in response to actual and expected impacts of climate change in the context of interacting non-climatic changes".

While there is growing awareness that many adaptation actions are local and build on experience of managing past climatic risks (Füssel 2007), there can be barriers and limitations to it (Baker et al. 2012; Biesbroek et al. 2014; Moser and Ekstrom 2010; Taylor et al. 2012). General definition of barriers to adaptation includes challenges, obstacles, constraints or hurdles that impede adaptation. These can come from several sources including lack of information or expertise, constraining resources, limited political support and leadership (Measham et al. 2011; Tribbia and Moser 2008; Baker et al. 2012; De Freitas et al. 2013; Ford and King 2015; Runharr et al. 2012) and a focus on short-term adaptation measures (Fidelman et al. 2013). In this paper, we define barriers as "obstacles that can be overcome with concerted effort, creative management, change of thinking, prioritization, and related shifts in resources, land uses, institutions". (Moser and Ekstrom 2010 , p. 22027). Simply put, barriers are the impediments that can compromise the adaptation process. It is, therefore, critically important to reduce the "adaptation deficit" between the implementation of adaptation with the everincreasing need for it. The identification and analysis of barriers to adaptation and possible opportunities to overcome them contributes towards reducing such deficit (Eisenack et al. 2014).
Further, climate change may also provide opportunities for enhancing adaptive capacity to climate impacts (Baker et al. 2012; Measham et al. 2011; Sales 2009). A range of enablers of adaptation has been reported in the literature including: the production of new, or integration and synthesis of existing information; policies, plans and programs; planning and natural resource management legislation; enabling new organisations and defining climate change mandate for existing ones; tools and guidelines to cope with climate impacts; and establishment of networks (Fidelman et al. 2013).

In the context of risks and opportunities associated with climate change, discussed above, this paper seeks to understand how key stakeholder groups perceive and respond to actual and potential climate-related changes. It uses the case of the North Coast of São Paulo, Brazil to underscore barriers and opportunities for adaptation in a coastal urban setting.

\section{Diagnosing barriers to adaptation}

This study draws on the framework of Moser and Ekstrom (2010) to diagnose barriers and opportunities for climate change adaptation. We focus particularly on the process component of the diagnostic framework as a foundation for identifying and organising barriers and opportunities. This component describes adaptation as a rational decisionmaking process consisting of three broad phases, i.e. (1) understanding the problem, (2) planning adaptation options and (3) managing implementation of such options. Each of these phases includes a series of stages: understanding involves problem detection, information gathering and problem definition; planning involves development of adaptation options, assessment and selection of options; and management involves implementation of selected options, monitoring outcomes from these options and evaluation. Each of these stages, in turn, identifies common barriers based on the adaptation literature (Moser and Ekstrom 2010) (Appendix 1 in electronic supplementary material). Competing priorities (P1.7), existing management context (M1.8) and existing ecological context (M1.9) are our additions to the list of common barriers identified by Moser and Ekstrom (2010). They emerged as important barriers identified over the course of this study.

Importantly, barriers may also be conceptualised as opportunities when preconditions to overcome these barriers are identified, and which when implemented, can generate positive externalities (e.g. lack in technical qualification can be perceived as an opportunity if there is local/regional capacity to produce relevant knowledge). Further, focusing on opportunities is critical to moving forward and finding solutions to barriers (Evans et al. 2016; 
Kettle and Dow 2014). Therefore, the list of barriers was also used to identify and organise opportunities for adaptation.

\section{Contextualizing the Brazilian coastal zone and the study region}

\section{Geographical and socio-economic context}

The Brazilian coastal zone covers $324,000 \mathrm{~km}^{2}$ and has a population density of 121 people $/ \mathrm{km}^{2}$, which is six times the national average (Brasil 2008). The North Coast of São Paulo state encompasses an area of $1944 \mathrm{~km}^{2}$ and an estimated population of 281,778 inhabitants across four municipalities: São Sebastião, Ilhabela, Caraguatatuba and Ubatuba (IBGE 2011). It is located between the metropolitan cities of Rio de Janeiro and São Paulo, a region of greatest economic development in Brazil (Fig. 1). The North Coast of São Paulo is bounded by the Serra do Mar, a long system of mountain ridges and escarpments parallel to the Atlantic coast. A large part of its area lies close to hillside conservation areas and are unsuitable for human settlement (Iwama et al. 2014). Similar to other coastal areas in Brazil, the North Coast faces multiple environmental and socio-economic pressures. The region has a history of major landslides and flooding, which are predicted to become more frequent and intense as a result of a changing climate (Iwama et al. 2014; Sakai et al. 2013).

The environmental and socio-economic characteristics of the North Coast municipalities make them susceptible to the impacts of climate change (Martins and Ferreira 2011). Such characteristics also have important implications for the ability of these municipalities to respond and adapt to such impacts. For example, the proximity of Serra do Mar makes these municipalities especially susceptible to orographic precipitation, and consequently intense runoff processes, river discharges, mass movements and landslides (Koga-Vicente and Nunes 2011; Sakai et al. 2013). Urban sprawl has extended into such susceptible areas making the North Coast's municipalities particularly vulnerable to environmental and climatic events (Inouye et al. 2015). Further, São Sebastião and Caraguatatuba feature

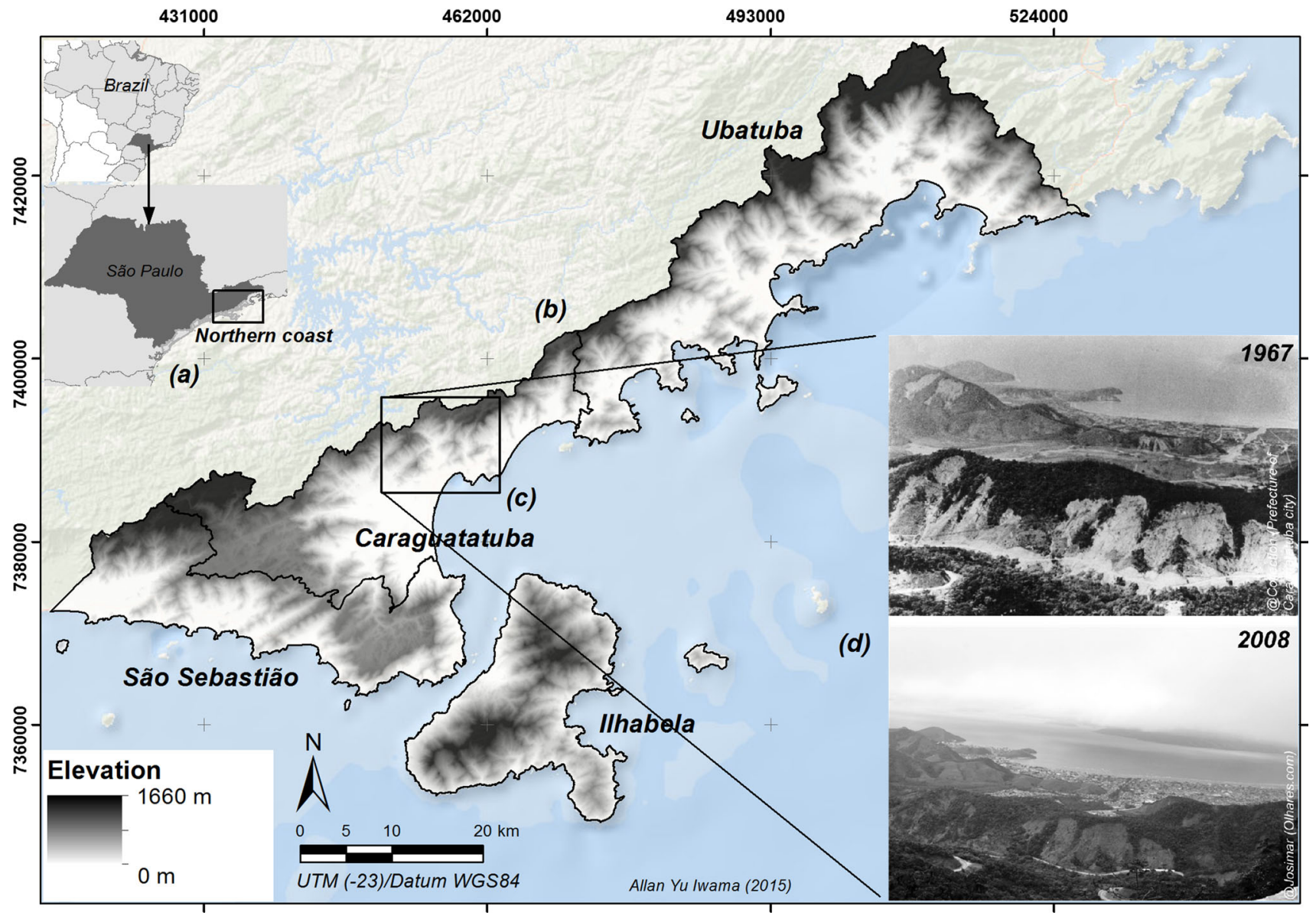

Fig. 1 North Coast of São Paulo comprising the municipalities of São Sebastião, Ilhabela, Caraguatatuba and Ubatuba. The pictures show areas affected by heavy rainfall in 1967 
expansion of the oil and gas industry and associated infrastructure, which pose risks and impacts involving oil spills and displacement of human populations (Teixeira 2013).

\section{Policy context for adaptation}

In Brazil, adaptation efforts are still developing at both national and sub-national levels. Nationally, there are three main policies relating to climate change adaptation: (1) the National Policy on Climate Change (PNMC), established in 2009 , includes multi-sector actions to reduce the vulnerability of human population to climate change; (2) National Adaptation Plan, a central component of the PNMC, involves the development of mitigation and adaptation plans; and (3) National Policy on Protection and Civil Defence (PNPDEC), launched in 2012, addresses in an integrated manner prevention, mitigation, preparedness, response and recovery issues pertaining to civil defence. In addition, the National Coastal Management Plan (Brasil 1988), despite not addressing climate adaptation directly, provides guidelines for implementing sustainable development related policies, plans and programs. The plan mandates that coastal states develop coastal management plans and ecological-economic zoning (EEZ-LN). Those were developed for the North Coast of São Paulo in 1998 and 2004, respectively.

São Paulo, the largest Brazilian state in terms of population and economic development, is the leading state on climate adaptation strategies. These include a State Policy on Climate Change (São Paulo 2009), which underlines the EEZ as a fundamental instrument for environmental planning and a framework for sustainable development. Additionally, the State Program for Prevention of Natural Disasters and Geological Hazard Mitigation (PDN) was established in 2011. Despite the initial progress in developing climate change response strategies, the translation of such strategies into action has been limited, particularly those to protect coastal populations and infrastructure in vulnerable areas (Barbi and Ferreira 2013; Iwama et al. 2014; Inouye et al. 2015).

\section{Methods}

This study was framed by the diagnostic framework conceptualised above and used a mixed method approach. In 2015 , a survey was administered online and face-to-face to explore barriers and opportunities for climate change adaptation. The survey also explored stakeholder perceptions of climate and non-climate risks, and existing efforts that may contribute to climate change adaptation (see questionnaire in Appendix 2 in electronic supplementary material).
The survey questionnaire consisted of thirty-six questions exploring stakeholder's perception of climate and non-climate risks and impacts; the involvement of their organisation in adaptation efforts; and resources, information and knowledge and policy influence underpinning their organisations capacity to engage in such efforts. Open questions meant many of the relevant themes could appear in multiple answers; thus, interview transcripts were coded and later consolidated into those themes. Open questions allowed respondents with opportunity to reflect on the most important elements within the understanding, planning and managing phase that promoted or hindered climate adaptation within their organisation and identify opportunity for change. The survey was administered to 49 individuals comprising representatives from 42 different organisations, including high-level government decision and policymakers, environmental non-governmental organisations, businesses and local industry and professional associations (Appendix 3 in electronic supplementary material). The respondents were selected based on their participation in the existing coastal management initiatives on the North Coast of São Paulo (e.g. members of the Watershed Committee, Coastal Management Review Group and protected areas advisory committees), workshops organised by the RedeLitoral Project (which this study was part) and other events focusing on coastal management in the region between 2013 and 2014.

This study involved two stages. First, common barriers to the different phases and stages of the adaptation process (Appendix 1 in electronic supplementary material) were used as a heuristic to systematically identify and categorise barriers and opportunities to adaptation. We then identified the main barriers [i.e. detection and perception of signal (U1.2) and threshold of concern (U1.3), leadership (P1.1) and existing management context (M1.8)] and analysed them in further detail. At this second stage, our study of leadership (P1.1) focussed on perceptions of organisations engaged in coastal management and climate change adaptation. We categorised organisations influence according to the frequency that stakeholders mentioned them as influential. Organisations with more than 15 mentions were categorised as "most influential", between 10 and 15 mentions as "influential", between 5 and 10 mentions as "somewhat influential" and $<5$ mentions as "least influential". We then linked the organisation to existing national, state and municipal coastal management and climate change efforts (M1.8) and classified whether their engagement in such efforts was direct, indirect, and optional or unrelated. In this regard, "direct" referred to organisations whose role in climate change and civil defence efforts was explicitly stated in the PNMC, PNPDEC or PEMC; "indirect" referred to organisations whose such role was not explicitly stated in the PNMC, 
PNPDEC or PEMC; but, it could be established through associations; "optional" referred to organisations whose such role was not explicitly stated in the PNMC, PNPDEC or PEMC; but, they could potentially play a role in climate change and civil defence efforts; while "UNRELATED" referred to organisations whose such role was not stated in the PNMC, PNPDEC or PEMC, and could not otherwise be implied.

Existing coastal management and climate change adaptation initiatives (M1.8) were examined in terms of how they addressed the main climate change threats identified in IPCC (2014) for Central and South America and the draft of the Brazil's National Adaptation Plan. Data analysis was performed with the software NVivo.

\section{Results}

\section{Common barriers and opportunities for adaptation}

Nineteen barriers and/or opportunities pertaining to the different phases of the adaptation process were identified for the North Coast of São Paulo (Table 1). Barriers pertaining to the understanding (U) phase were the most frequently noted by respondents $(43 \%)$. These barriers were associated particularly with detection (and perception) of signal (U1.2) (12 mentions), availability and accessibility of information (U2.2) (17 mentions) and level of agreement or consensus (U3.4) (13 mentions). Respondents perceived threats related to the region's socio-economic development as certain, while threats relating to climate change were mostly seen as possible, but not current and thus not urgent or difficult to manage. The following quote is illustrative:

Climate change isn't certain, but there is urban growth on the whole coast, thus it would be possible to adapt constructions to withstand sea level rise.

The understanding phase was also one which most of the barriers were nevertheless considered as opportunities, particularly detection (and perception) of a climate change signal (U1.2) (12 mentions as "barrier" and 13 as "opportunity"), and availability and accessibility (U2.2) of information (17 mentions as "barrier" and 20 mentions as "opportunity"). For example, participants were able to detect climate-related changes in the region (e.g. precipitation) although they did not necessarily link these changes to climate change. Further, respondents suggested that existing information channels could be used to disseminate local-scale information about climate risks and impacts.

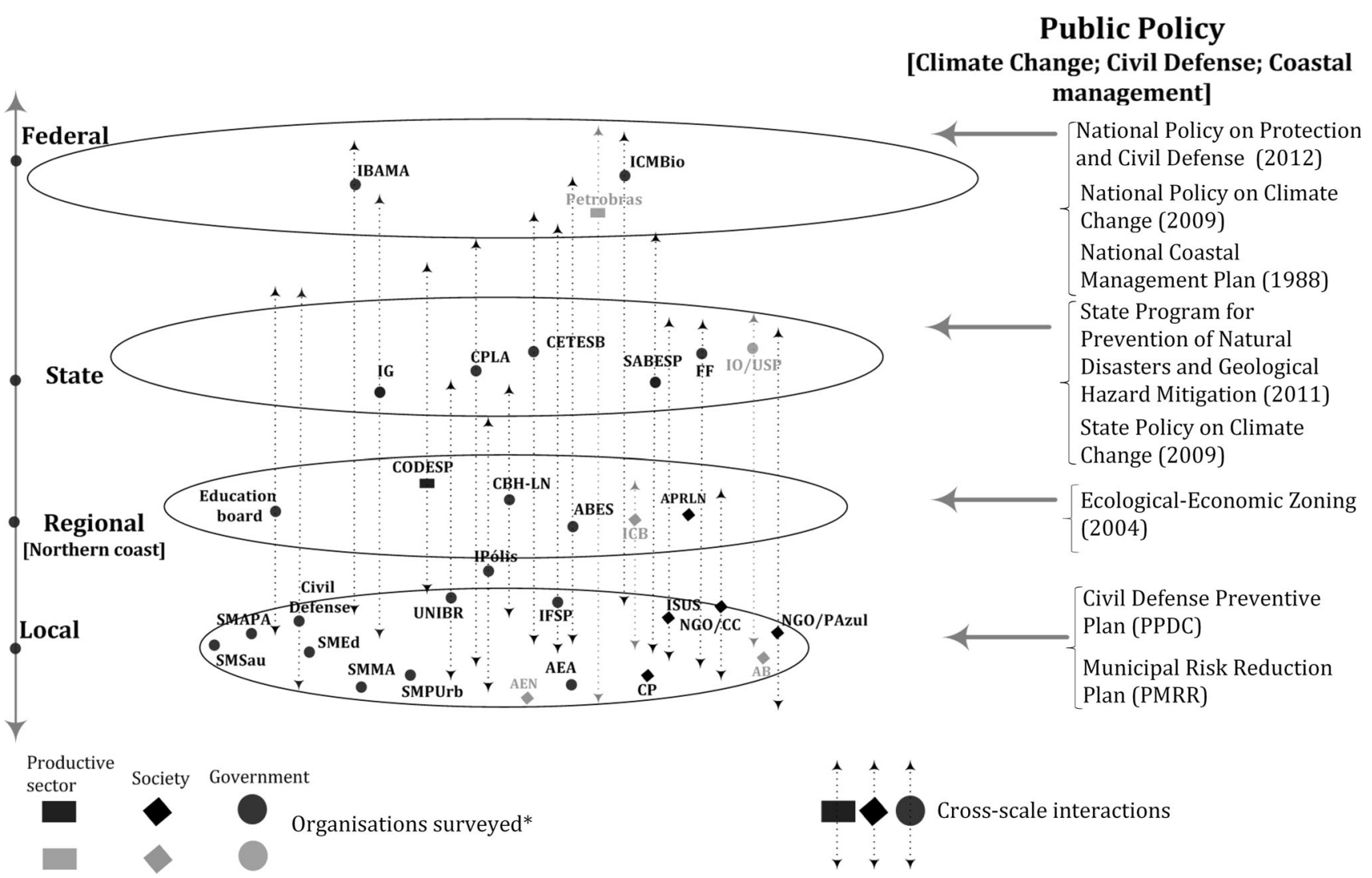

Fig. 2 Organisations surveyed and related public policies. Light grey symbols indicate organisations that completed the survey 
Table 1 Stakeholder perception of barriers and opportunities for climate change adaptation on the North Coast of São Paulo

\begin{tabular}{|c|c|c|c|}
\hline \multirow[t]{2}{*}{ Barrier/opportunity } & \multirow[t]{2}{*}{ Description } & \multicolumn{2}{|c|}{ No. of mention } \\
\hline & & Barrier & Opportunity \\
\hline U1.1 Existence of a signal & Visible and measurable risks to people and/or the environment & 06 & 05 \\
\hline U1.2 Detection (and perception) of signal & Recognition that risks identified are linked to climate change & 12 & 13 \\
\hline U1.3 Threshold of concern & $\begin{array}{l}\text { Engagement of various or some sectors of society and organisations } \\
\text { with efforts to address climate and non-climate risks }\end{array}$ & 00 & 03 \\
\hline U1.4 Threshold of response need and feasibility & Situations that require immediate action and viable response & 00 & 04 \\
\hline U2.2 Availability and accessibility of information & $\begin{array}{l}\text { Access to interpretable knowledge on relevant climate impacts; } \\
\text { availability of relevant education and capacity building } \\
\text { opportunities }\end{array}$ & 17 & 20 \\
\hline $\begin{array}{l}\text { U2.5 Credibility and trust (in the information and } \\
\text { its sources) }\end{array}$ & $\begin{array}{l}\text { Trust of the information and its sources resulting in not being well } \\
\text { received and not being discussed/addressed }\end{array}$ & 03 & 03 \\
\hline U2.6 Legitimacy & Role of professional-informal organisations & 02 & 00 \\
\hline U3.4 Level of agreement or consensus & $\begin{array}{l}\text { Understanding relevance of climate change, adaptation needs, and } \\
\text { trade-offs to other priorities. Once incorporated into political } \\
\text { agenda, policies are adopted promptly }\end{array}$ & 13 & 07 \\
\hline $\begin{array}{l}\text { P1.1 Leadership, including authority and skill in } \\
\text { driving the process }\end{array}$ & $\begin{array}{l}\text { Ability to define priorities and adapt existing programs to } \\
\text { incorporate new priorities. The absence of political will to engage } \\
\text { in climate adaptation issues constitutes a barrier }\end{array}$ & 20 & 12 \\
\hline P1.2 Ability to identify and agree on goals & $\begin{array}{l}\text { Progress in efforts contributing to adaptation (both climate and } \\
\text { non-climate driven) }\end{array}$ & 00 & 01 \\
\hline P1.7 Competing priorities & $\begin{array}{l}\text { Existence of focal areas considered to be more important or urgent } \\
\text { than climate adaptation }\end{array}$ & 16 & 00 \\
\hline $\begin{array}{l}\text { P3.2 Sphere of responsibility/influence/control } \\
\text { over options }\end{array}$ & $\begin{array}{l}\text { Autonomy to choose the areas of engagement and ability to plan } \\
\text { and execute chosen actions }\end{array}$ & 08 & 05 \\
\hline M1.2 Authorisation & Autonomy and support from own organisation & 02 & 00 \\
\hline M1.3 Sufficient resources & Human, technical and financial resources and time & 23 & 14 \\
\hline M1.6 Legality and procedural feasibility & $\begin{array}{l}\text { Structures and processes exist for enforcement of environmental } \\
\text { regulations and land-use planning }\end{array}$ & 00 & 03 \\
\hline $\begin{array}{l}\text { M1.7 Sufficient momentum to overcome } \\
\text { institutional stickiness, path dependency and } \\
\text { attitudinal obstacles }\end{array}$ & $\begin{array}{l}\text { Ability to change constraining attitudes to climate adaptation } \\
\text { towards those supporting it }\end{array}$ & 01 & 00 \\
\hline M1.8 Existing management context & $\begin{array}{l}\text { A range of climate and non-climate strategies supportive of } \\
\text { adaptation are in place }\end{array}$ & 00 & 26 \\
\hline M1.9 Existing ecological context & Ecosystem health, e.g. level of biodiversity conservation conditions & 00 & 01 \\
\hline Total & & 123 & 117 \\
\hline
\end{tabular}

In the planning phase, the lack of leadership (P1.1) was considered a significant barrier (20 mentions); and, yet an opportunity (12 mentions). Many respondents stated that fostering adaptation would require a mobilising agent. They suggested that organisations focusing on conservation or coastal planning are undertaking actions supportive of climate adaptation may be better positioned to play such leadership role. Further, leadership has important implications for other barriers/opportunities, such as authorisation (M1.2), resources (M1.3) and momentum (M1.7). The main opportunities for this phase included the existence of local capacity; i.e. organisations (e.g. Watershed Committees, protected area advisory boards and NGOs) that would be able to incorporate adaptation actions into their current activities.

Lack of resources (M1.3) was the most mentioned barrier (23 mentions) in the management phase. This included insufficient equipment, lack of technical capacity, limited funds and insufficient time. Nevertheless, 14 respondents noted that some existing resources could potentially be tapped into adaptation. These included the regional financing funds and other existing funding mechanisms, such as state water resources funds, royalties and environmental compensation funds associated with the expanding oil and gas industry. 


\section{Emerging critical barriers and/or opportunities for adaptation}

\section{Detection (and perception) of signal and availability and accessibility of information (U1.2, U2.2)}

Eighty-four percentage of respondents perceived environmental change signals on the North Coast of São Paulo. Respondents frequently mentioned changes to the pattern of rainfall [14 mentions (34\%)] and higher frequency of landslides [9 mentions (22\%)] and flooding [7 mentions $(17 \%)]$ associated with extreme precipitation and unregulated land occupation. Sixty-seven percentage of the interviewees identified an increase in natural disasters, including landslides and floods. Other perceived environmental changes included change in temperature [5 mentions $(12 \%)$ ], sea level rise [5 mentions $(12 \%)$ ], coastal erosion [4 mentions (10\%)], increase in storms (waves) [2 mentions (5\%)], change in wind conditions [2 mentions $(5 \%)$ ], proliferation of diseases [2 mentions (5\%)], irregular land occupation [1 mentions (2\%)] and siltation of rivers [1 mentions $(2 \%)]$.

Further, representatives from the small-scale fishery were concerned about potential impacts of climate change on fishing stocks (in terms of quantity, distribution and seasonality). Likewise, representatives from agriculture were concerned about the impact of changed rainfall patterns and spread of invasive species. Respondents primarily related environmental changes to rapid development of the North Coast; some of them regarded climate change only as a potential exacerbating factor. For example, respondents frequently noted that the proliferation of dengue fever was related to the increase in temperature. However, they were unable to relate it to climate change. In addition, they did not perceive climate change as urgent or difficult issue to manage. These may explain why only a few organisations had incorporated climate change into their portfolios. An example is the North Coast Watershed Committee includes climate change impacts in its management plans. Similarly, the state agency Fundação Florestal requires that protected area management plans include potential climate change impacts. Most respondents identified a lack of information on impacts at the local scale.

\section{Existing management context (M1.8)}

As noted previously, the existing management context refers to climate and non-climate efforts supportive of adaptation. Respondents reported a wide range of activities undertaken by their organisations, which addresses key climate change risks and impacts (Table 2). These activities focused on minimising the risk of disasters from extreme events, such as flooding, erosion and landslides. This also includes activities to reduce the impacts from urban expansion, such as the construction of dikes and breakwaters, use of sustainable construction techniques, improved drainage systems, river dredging and sewage treatment system. Similarly, various planning instruments contribute to adaptation, for example, by limiting urban expansion in vulnerable areas. Further, legislation relating to coastal management and civil defence has provided for monitoring and enforcement that support adaptive capacity. This includes monitoring rainfall and establishing thresholds for evacuation of vulnerable areas. Other activities reported by respondents have focused on learning and, therefore, building adaptive capacity. Such activities include, for example, a social learning process developed by the revision of the ecological-economic zoning (EEZ) working group.

\section{Leadership (P1.1)}

Thirty-two respondents identified 108 organisations and groups they see as relevant or influential in climate change adaptation at different governance levels [e.g. Municipal Plan of Risk Reduction at local level, and National Plan of Climate Change] at the federal level (Fig. 2). However, actions across these organisations are yet to be adequately coordinated, especially in relation to climate change adaptation. For example, the state climate change policy influences the actions of the State Department for Environmental Planning; but, not those of municipal governments.

Perception about the relevance of different organisations in responding to climate change varied among respondents. However, there was an overall consensus about the level of influence of those organisations regarding climate change adaptation. Organisations ranked as more influential were local councils and protected area management entities (e.g. Fundação Florestal was mentioned 15 times), local council environmental departments (SMMA), civil defence, universities, state environmental agency (SMA), non-governmental organisations, Watershed Committee (CBH-LN) and Public Prosecutor (mentioned between 10 and 15 times). The least cited organisations (scoring between 5 and 10 mentions) included: the Ministry of Environment (MMA), National Centre for Monitoring and Natural Disasters Warning (CEMADEN), State Civil Defence and Regional Directorate of Education (Education Board) (Fig. 3).

Interestingly, some of the organisations with legal responsibility over climate-related actions were perceived as not being relevant or influential in adaptation. These include the National Centre for Natural Disaster Monitoring and Warning (CEMADEN), Geological Institute (IG), 
Table 2 Activities addressing key climate change risks on the North Coast of São Paulo (IPCC 2014; Brasil 2016)

\begin{tabular}{|c|c|c|c|c|c|c|c|c|}
\hline \multirow[t]{2}{*}{ Activity } & \multicolumn{8}{|l|}{ Risk } \\
\hline & $\begin{array}{l}\text { Extreme } \\
\text { precipitations } \\
\text { causing } \\
\text { flooding and } \\
\text { landslides }\end{array}$ & $\begin{array}{l}\text { Decreased } \\
\text { food } \\
\text { production } \\
\text { and food } \\
\text { quality }\end{array}$ & $\begin{array}{l}\text { Spread } \\
\text { of } \\
\text { vector- } \\
\text { borne } \\
\text { diseases }\end{array}$ & $\begin{array}{l}\text { Erosion/ } \\
\text { sea } \\
\text { level } \\
\text { rise }\end{array}$ & $\begin{array}{l}\text { Saltwater } \\
\text { intrusion } \\
\text { by the sea } \\
\text { level rise }\end{array}$ & $\begin{array}{l}\text { Natural } \\
\text { resources } \\
\text { and } \\
\text { biodiversity } \\
\text { loss }\end{array}$ & $\begin{array}{l}\text { Increase in } \\
\text { extratropical } \\
\text { cyclones' } \\
\text { frequency }\end{array}$ & Acidification \\
\hline Alternative energy systems & $\bullet$ & $\bullet \sqrt{ }$ & $\bullet$ & $\bullet$ & $\bullet$ & $\bullet$ & $\bullet$ & $\bullet$ \\
\hline $\begin{array}{l}\text { Strategic integrated } \\
\text { environmental } \\
\text { assessment in licensing } \\
\text { process (cumulative } \\
\text { effects analysis) }\end{array}$ & $\cdot \sqrt{ }$ & $\sqrt{ }$ & $\sqrt{ }$ & $\sqrt{ }$ & $\sqrt{ }$ & $\cdot \sqrt{ }$ & $\sqrt{ }$ & $\sqrt{ }$ \\
\hline $\begin{array}{l}\text { Low impact construction } \\
\text { techniques }\end{array}$ & $\sqrt{ }$ & $\sqrt{ }$ & $\sqrt{ }$ & $\sqrt{ }$ & $\sqrt{ }$ & $\sqrt{ }$ & & \\
\hline Biodiversity conservation & $\cdot \sqrt{ }$ & & $\cdot \sqrt{ }$ & & $\bullet \sqrt{ }$ & $\cdot \sqrt{ }$ & & \\
\hline Territorial planning & $\sqrt{ }$ & $\cdot \sqrt{ }$ & $\sqrt{ }$ & $\sqrt{ }$ & $\sqrt{ }$ & $\cdot \sqrt{ }$ & & \\
\hline Urban planning & $\sqrt{ }$ & $\sqrt{ }$ & $\sqrt{ }$ & $\sqrt{ }$ & $\sqrt{ }$ & $\sqrt{ }$ & & \\
\hline $\begin{array}{l}\text { Environmental monitoring } \\
\text { and control }\end{array}$ & $\sqrt{ }$ & $\sqrt{ }$ & $\sqrt{ }$ & $\sqrt{ }$ & $\sqrt{ }$ & $\sqrt{ }$ & $\sqrt{ }$ & \\
\hline Restoration of vegetation & $\cdot \sqrt{ }$ & & $\cdot \sqrt{ }$ & & & $\cdot \sqrt{ }$ & & \\
\hline $\begin{array}{l}\text { Local and sustainable food } \\
\text { production }\end{array}$ & $\sqrt{ }$ & $\sqrt{ }$ & $\sqrt{ }$ & & & $\sqrt{ }$ & & \\
\hline $\begin{array}{l}\text { Food security in public } \\
\text { schools based on local } \\
\text { production }\end{array}$ & $\sqrt{ }$ & $\sqrt{ }$ & $\sqrt{ }$ & & & $\sqrt{ }$ & & \\
\hline Pollution reduction & & $\sqrt{ }$ & $\sqrt{ }$ & & & $\sqrt{ }$ & & \\
\hline Pollution control & & $\sqrt{ }$ & $\sqrt{ }$ & & & $\sqrt{ }$ & & \\
\hline Improved drainage & $\sqrt{ }$ & & $\sqrt{ }$ & $\sqrt{ }$ & & & & \\
\hline Solid waste management & & $\sqrt{ }$ & $\sqrt{ }$ & & & $\sqrt{ }$ & & \\
\hline Sea walls & $\sqrt{ }$ & & & $\sqrt{ }$ & & & & \\
\hline Sanitation systems & & $\sqrt{ }$ & $\sqrt{ }$ & & & $\sqrt{ }$ & & \\
\hline Land-use risk management & $\sqrt{ }$ & & $\sqrt{ }$ & $\sqrt{ }$ & $\sqrt{ }$ & $\sqrt{ }$ & & \\
\hline $\begin{array}{l}\text { Monitoring and warn those } \\
\text { living in risk areas }\end{array}$ & $\sqrt{ }$ & $\sqrt{ }$ & $\sqrt{ }$ & $\sqrt{ }$ & $\sqrt{ }$ & $\sqrt{ }$ & $\sqrt{ }$ & $\sqrt{ }$ \\
\hline $\begin{array}{l}\text { Environmental education } \\
\text { and capacitation } \\
\text { processes }\end{array}$ & $\sqrt{ }$ & $\sqrt{ }$ & $\sqrt{ }$ & $\sqrt{ }$ & $\sqrt{ }$ & $\sqrt{ }$ & $\sqrt{ }$ & $\sqrt{ }$ \\
\hline Research & $\cdot \sqrt{ }$ & $\bullet \sqrt{ }$ & $\cdot \sqrt{ }$ & $\cdot \sqrt{ }$ & $\cdot \sqrt{ }$ & $\cdot \sqrt{ }$ & $\cdot \sqrt{ }$ & $\cdot \sqrt{ }$ \\
\hline $\begin{array}{l}\text { Capacity building events } \\
\text { (workshops, seminars) }\end{array}$ & $\sqrt{ }$ & $\sqrt{ }$ & $\sqrt{ }$ & $\sqrt{ }$ & & $\sqrt{ }$ & & \\
\hline Water storage & & $\sqrt{ }$ & & & $\sqrt{ }$ & $\sqrt{ }$ & & \\
\hline Resilient infrastructure & $\sqrt{ }$ & $\sqrt{ }$ & $\sqrt{ }$ & $\sqrt{ }$ & & $\sqrt{ }$ & & \\
\hline
\end{tabular}

$\sqrt{ }=$ local and regional or micro-level activities; $\bullet$ = global-level activities

Institute of Technological Research (IPT), Ministry of Environment (MMA), State Environmental Department (SMA) and State Civil Defence. On the other hand, a number of organisations perceived as relevant or influential (35 from the 108 organisations mentioned), despite not having a formal role in the public policies analysed (e.g. protected area management entities, universities, Watershed Committee and NGOs), suggests they could eventually play a role in climate adaptation in the region (Fig. 3).

\section{Discussion}

This study examined challenges and opportunities for climate adaptation in the context of coastal management on the North Coast of São Paulo. Among the several barriers and opportunities identified, detection and perception of signal, existing management context and leadership emerged as the most critical ones. Addressing barriers and capitalising on opportunities would require improving 


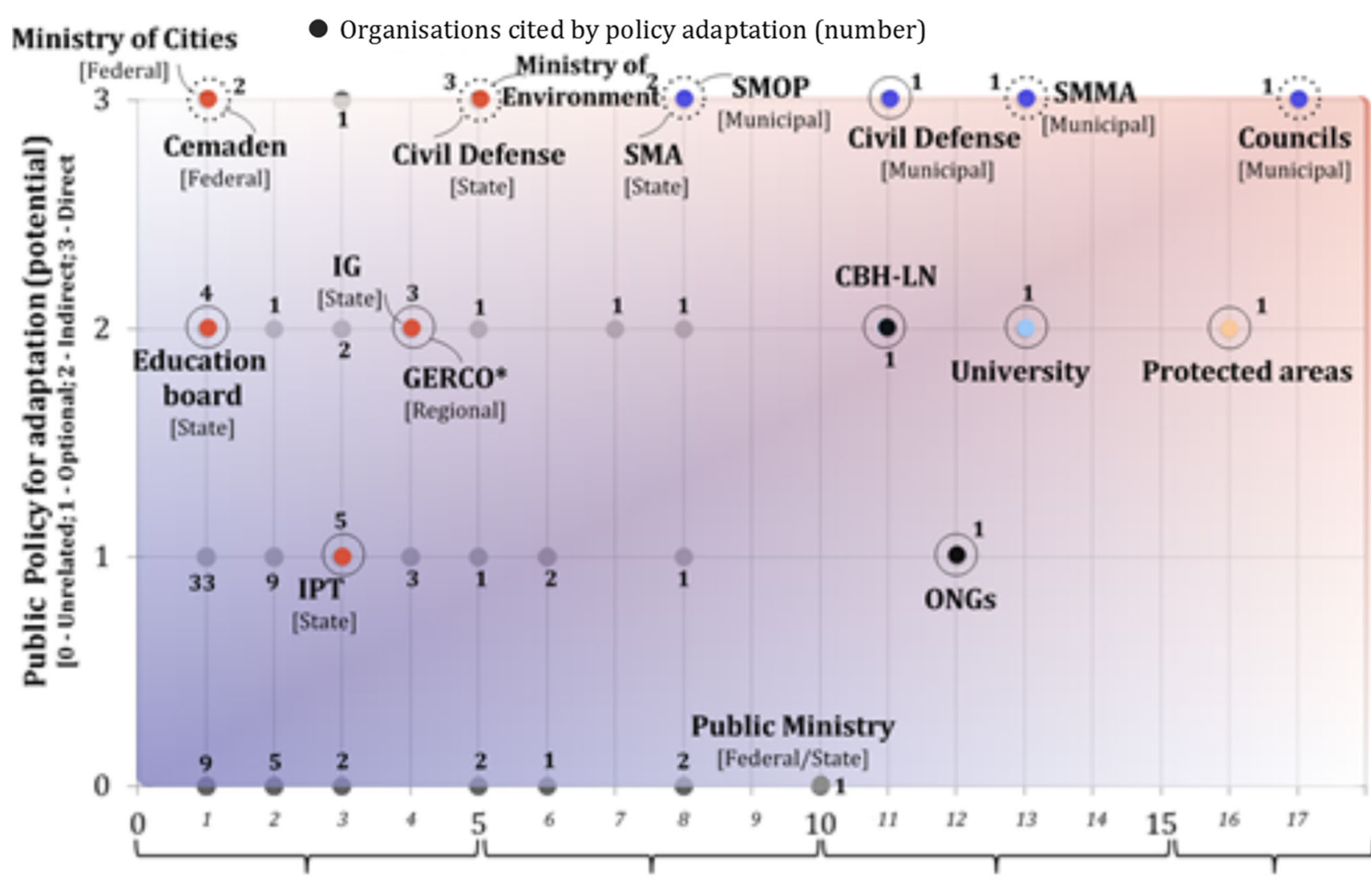

[Total organisations $=82] \quad$ [Total organisations $=19]$

[Total organisations $=6] \quad$ [Total organisations $=1$ ]

Total organisations (by citation)

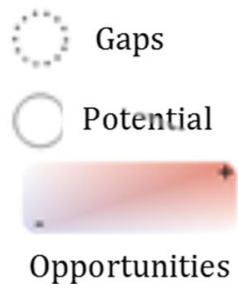
Direct relation for policy adaptation, and low-mid organisations
Direct relation for policy adaptation, and mid-high organisations
Unrelated for policy adaptation, and mid-high organisations
Indirect relation for policy adaptation, and low-mid organisations

\section{Indirect relation for policy adaptation, and mid-high organisations}

Optional for policy adaptation, and mid-high organisations

Fig. 3 Perception of stakeholders about the relevance or influence of the most cited organisations in responding to climate-related and adaptation issues. See Appendix 3 in electronic supplementary material for abbreviations

perception about climate change and availability and accessibility of information, fostering anticipatory planned adaptation through the existing management context and developing leadership for adaptation. These are discussed below.

\section{Improving perception about climate change and availability and accessibility of information}

Several factors may explain the failure of many respondents-including those who experience climate-related events first-hand-to link environmental change signals to climate change. For instance, while some information on climate change is available for the region (U1.2), there is limited engagement between scientists and decision- makers. Further, such studies are not readily available and accessible to decision-makers (U2.2). This is illustrative of knowledge being shared among peers, or by means of academic publications not reaching a large portion of society (e.g. Tribbia and Moser 2008; Biesbroek et al. 2013). Further, current understanding on the nature of barriers to adaptation is suggested to be "limited and highly fragmented across the academic community" (Biesbroek et al. 2013, p. 1119).

It is, therefore, imperative to make available and accessible information on climate risks and impacts if response strategies (e.g. adaptation) are to be developed (Lindell and Hwang 2008). This includes disseminating information about the links between climate changes and local weather events, when they exist (Spence et al. 2011). 
In this context, respondents indicated the need for actions evidencing potential effects, scenarios and forecasts to raise awareness and identify appropriate response strategies (e.g. monitoring of extreme weather events). The use of scenario models is another way to produce and disseminate relevant information (Evans et al. 2013; Ford and King 2015; Di Giulio et al. 2014). Such models comprise a strategic decision-making tool for addressing climate change through participatory diagnostics and, ultimately, adaptive measures (PROVIA 2013).

Furthermore, because adaptation requires learning, both public and private sector organisations need to build capacity to process and interpret information on climate change risks and impacts (Barnett et al. 2014; Kettle and Dow 2014). It is, therefore, imperative to improve our understanding of how different groups interpret and assign meaning to social-environmental phenomena differently (and sometimes conflicting), which in turn influence ideas about the significance and prioritization of barriers to adaptation (Biesbroek et al. 2013).

\section{Fostering anticipatory planned adaptation through the existing management context}

The response strategies to climate and non-climate threats analysed in this study consist mostly of coping strategies (M1.8). They result in part from public policies that are reactive (Iwama et al. 2014, 2016) and have been compounded by inadequate resources (M1.3) and, particularly, competing priorities (P1.7). Similar to other nations, these are common barriers to adaptation associated with political imperatives that emphasise reducing short-term risks rather than long-term strategic planning (see e.g. Ford et al. 2011).

Given the long-term nature of climate change, adaptation strategies should have a long-term focus allowing for adjustments in anticipation to climate change impacts (Luers and Moser 2006). Ultimately, these strategies should entail actions that promote more fundamental shift in the system in light of undesirable conditions (Nelson et al. 2007). Fostering such anticipatory planned approach would benefit from the existing management context (M1.8) examined above. This would involve mainstreaming adaptation into existing planning processes, which would also provide opportunities for building and mobilising adaptive capacity (McSweeney et al. 2010). Further, the existing management context also includes collaborative decision-making involving multiple stakeholders, such as the North Coast Watershed Committee (Iwama et al. 2014). It would serve as adequate platforms for linking stakeholders to the design and implementation of adaptation-related policies (Kettle and Dow 2014; Shaw et al. 2013). Last, current management efforts involve multiple sectors, governance levels (Fig. 2) and interconnected issues (Table 2). Anticipatory planned adaptation should be strategic, taking into account interdependencies across those sectors, governance and issues (Fidelman et al. 2013).

\section{Developing leadership for adaptation}

Leadership is critical for adaptation when it points to (a) direction(s) and motivates others to follow (Gupta et al. 2010). Respondents perceived many local and regional organisations without a climate change mandate as relevant or influential for climate adaptation (P1.1). Developing leadership for adaptation would benefit from mainstreaming climate change into the activities of these organisations, as discussed above. As well pointed by Eisenack et al. (2014), regardless of the position or authority role, leadership (particularly in the early stages of adaptation) with clear responsibilities can entail new governance mechanisms and changed context for decision-making. In this context, the concept of boundary organisations may prove relevant if leaders are responsible for effective brokering of information, e.g. between knowledge (technical and local) and governance systems (Vogel et al. 2007). Ultimately, they would perform intermediary functions between knowledge and practice (Lynch et al. 2008; Shaw et al. 2013). Another important leadership role would be capacity building, particularly, decision-making capacity. On the North Coast of São Paulo, this would require overcoming the perceived limited financial and technical resources noted above. In any case, the role of leading organisations needs to be considered with caution. In many instances, it has resulted in abuse of power, stalled social learning and dominance of particular interests, undermined ownership among stakeholders and challenged coordination of adaptation activities (Eisenack et al. 2014).

\section{Concluding remarks}

This study drew on the framework of Moser and Ekstrom (2010) to diagnose barriers to climate change adaptation in a coastal urban context where adaptation is in its infancy. In such context, we identified additional barriers to those proposed in diagnostic framework; therefore, expanding their diagnostic capability. These barriers include competing priorities pertaining to the planning phase of the adaptation process, and the existing ecological and management contexts pertaining to the management phase of such process. Importantly, this study also conceptualised barriers to climate change adaptation in terms of opportunities to highlight some of the preconditions to overcome barriers. In this context, detection and perception of signal, 
availability and accessibility of information, existing management context and leadership emerged as critical barriers and/or opportunities for climate change adaptation. We propose that addressing these barriers and opportunities will involve improving perception about climate change and availability and accessibility of information, fostering anticipatory planned adaptation through the existing management context and developing leadership for adaptation. Findings from this study may prove useful to other jurisdictions, particularly those where climate adaptation is in its early stages of development.

Acknowledgements This research was funded by CAPES/RedeLitoral (Project CAPES 417/2010). The authors would like to thank the participants who took part in this study. We also thank the two anonymous reviewers for their constructive comments.

\section{References}

Adger WN (2003) Social capital, collective action and adaptation to climate change. Econ Geogr 79:387-404. doi:10.1007/978-3531-92258-4_19

Adger WN, Arnell NW, Tompkins EL (2005) Successful adaptation to climate change across scales. Glob Environ Change 15:77-86. doi:10.1016/j.gloenvcha.2004.12.005

Baker I, Peterson A, Brown G, McAlpinea C (2012) Local government response to the impacts of climate change: an evaluation of local climate adaptation plans. Landsc Urban Plan 107(2):127-136. doi:10.1016/j.landurbplan.2012.05.009

Barbi F, Ferreira LC (2013) Risks and political responses to climate change in Brazilian coastal cities. J Risk Res. doi:10.1080/ 13669877.2013.788548

Barnett J, Graham S, Mortreux C, Fincher R, Waters E, Hurlimann A (2014) A local coastal adaptation pathway. Nat Clim Change 4(12):1103-1108. doi:10.1038/nclimate2383

Biesbroek GR, Klostermann JEM, Termeer CJAM, Kabat P (2013) On the nature of barriers to climate change adaptation. Reg Environ Change 13:1119-1129. doi:10.1007/s10113-013-0421-y

Biesbroek GR, Termeer CJAM, Klostermann JEM, Kabat P (2014) Analytical lenses on barriers in the governance of climate change adaptation. Mitig Adapt Strateg Glob Change 19(7):1011-1032. doi:10.1007/s11027-013-9457-z

Bradley M, Van Putten I, Sheaves M (2015) The pace and progress of adaptation: marine climate change preparedness in Australia's coastal communities. Mar Policy 53:13-20. doi:10.1016/j. marpol.2014.11.004

Brasil - Law $\mathrm{n}^{\circ} 7.661$ (1988) Plano Nacional de Gerenciamento Costeiro - PNGC. Available at http://www.planalto.gov.br/ ccivil_03/leis/L7661.htm

Brasil. Ministério do Meio Ambiente (MMA) (2008) Macrodiagnóstico da Zona Costeira e Marinha do Brasil. MMA, Brasília

Brasil-Plano Nacional de Adaptação à Mudança do Clima-PNA (2016) Ministério do Meio Ambiente, Portaria 150. Available at http://www.mma.gov.br/clima/adaptacao/plano-nacional-deadaptacao

Burrows MT, Schoeman DS, Buckley LB, Moore P (2011) The pace of shifting climate in marine and terrestrial ecosystems. Science 334:652-655. doi:10.1126/science. 1210288

Cooper JAG, Pile J (2014) The adaptation-resistance spectrum: a classification of contemporary adaptation approaches to climate- related coastal change. Ocean Coast Manag 94:90-98. doi:10. 1016/j.ocecoaman.2013.09.006

De Freitas DM, Smith TF, Stokes A (2013) Planning for uncertainty: local scale coastal governance. Ocean Coast Manag 86:72-74. doi:10.1016/j.ocecoaman.2013.10.011

Di Giulio GM, Neumann SS, Viglio JE, Ferreira LD, Choy DL (2014) Propostas metodológicas em pesquisas sobre risco e adaptação: experiências no Brasil e na Austrália. Ambiente Soc 17(4):35-54

Dutra LXC, Bustamante RH, Sporne I, Putten IV, Dichmont CM, Ligtermoet E, Sheaves M, Deng RA (2015) Organizational drivers that strengthen adaptive capacity in the coastal zone of Australia. Ocean Coast Manag 109:64-76. doi:10.1016/j.ocecoa man.2015.02.008

Eisenack K, Moser SC, Hoffmann E, Klein RJT, Oberlack C, Pechan A, Rotter M, Termeer CJAM (2014) Explaining and overcoming barriers to climate change adaptation. Nat Clim Change 4:867-872. doi:10.1038/nclimate2350

European Commission (2007) Adapting to climate change in Europe-options for EU action. Green Paper, EC, Brussels. $\operatorname{COM}(2007) 354$ final

Evans LS, Hicks CC, Fidelman P, Tobin RC, Perry AL (2013) Future scenarios as a research tool: investigating climate change impacts, adaptation options and outcomes for the great barrier reef, Australia. Hum Ecol 41(6):841-857. doi:10.1007/s10745013-9601-0

Evans LS, Hicks CC, Adger WN, Barnett J, Perry AL, Fidelman P, Tobin R, Clifton J (2016) Structural and psycho-social limits to climate change adaptation in the great barrier reef region. PLoS One 11(3):e0150575. doi:10.1371/journal.pone.0150575

Fidelman PIJ, Leitch AM, Nelson DR (2013) Unpacking multilevel adaptation to climate change in the great barrier reef, Australia. Glob Environ Change 23(4):800-812. doi:10.1016/j.gloenvcha. 2013.02.016

Ford JD, King D (2015) A framework for examining adaptation readiness. Mitig Adapt Strateg Glob Change 20(4):505-526. doi:10.1007/s11027-013-9505-8

Ford JD, Berrang-Ford L, Paterson J (2011) A systematic review of observed climate change adaptation in developed nations. Clim Change 106:327-336. doi:10.1007/s10584-011-0045-5

Füssel HM (2007) Adaptation planning for climate change: concepts, assessment approaches and key lessons. Sustain Sci 2:265-275. doi:10.1007/s11625-007-0032-y

Gibbs MT (2015) Coastal climate risk and adaptation studies: the importance of understanding different classes of problem. Ocean Coast Manag 103:9-13. doi:10.1016/j.ocecoaman.2014.10.018

Gupta J, Termeer C, Klostermann J, Meijerink S (2010) The adaptive capacity wheel: a method to assess the inherent characteristics of institutions to enable the adaptive capacity of society. Environ Sci Policy 13(6):459-471. doi:10.1016/j.envsci.2010.05.006

IBGE (2011) Demographic census 2010. Rio de Janeiro, 2011. http:// www.ibge.gov.br/. Accessed 20 July 2015

IBGE (2015) IBGE Cidades. http://cidades.ibge.gov.br. Accessed 17 July 2015

Inouye CEN, De Sousa WC, De Freitas DM, Simões E (2015) Modelling the spatial dynamics of urban growth and land use changes in the north coast of São Paulo, Brazil. Ocean Coast Manag 108:147-157. doi:10.1016/j.ocecoaman.2014.12.016

IPCC (2014) Summary for policymakers. In: Climate Change 2014: Impacts, Adaptation, and Vulnerability. Part A: Global and Sectoral Aspects. Contribution of Working Group II to the Fifth Assessment Report of the Intergovernmental Panel on Climate Change [Field, C.B., V.R. Barros, D.J. Dokken, K.J. Mach, M.D. Mastrandrea, T.E. Bilir, M. Chatterjee, K.L. Ebi, Y.O. Estrada, R.C. Genova, B. Girma, E.S. Kissel, A.N. Levy, S. MacCracken, P.R. Mastrandrea, and L.L. White (eds)]. Cambridge University 
Press, Cambridge, United Kingdom and New York, NY, USA, pp 1-32

Iwama AY, Batistella M, Ferreira LC (2014) Geotechnical risks and social vulnerability in coastal areas: inequalities and climate change. Ambiente Soc 17(4):251-274. doi:10.1590/18094422ASOC1149V1742014

Iwama AY, Batistella M, Ferreira Lúcia C, Alves DS, Ferreira Leila C (2016) Risk, vulnerability and adaptation to climate change: an interdisciplinary approach. Ambiente Soc 19(2):93-116. doi:10. 1590/1809-4422ASOC137409V1922016

Kettle NP, Dow K (2014) Cross-level differences and similarities in coastal climate change adaptation planning. Environ Sci Policy 44:279-290. doi:10.1016/j.envsci.2014.08.013

Koga-Vicente A, Nunes LH (2011) Impactos socioambientais associados à precipitação em municípios do litoral paulista. Geografia 36(3):571-588. ISSN 1983-8700. http://www.period icos.rc.biblioteca.unesp.br/index.php/ageteo/article/view/8460

Lindell MK, Hwang SN (2008) Households' perceived personal risk and responses in a multihazard environment. Risk Anal 28(2):539-556. doi:10.1111/j.1539-6924.2008.01032.x

Luers AL, Moser SC (2006) Preparing for the impacts of climate change in California: opportunities and constraints for adaptation. California Climate Change Center White Paper

Lynch AH, Tryhorn L, Abramson R (2008) Working at the boundary: facilitating interdisciplinarity in climate change adaptation research. Bull Am Meteorol Soc 89:169-179. doi:10.1175/ BAMS-89-2-169

Martins RD, Ferreira LC (2011) Governing climate change: urbanization, vulnerability and challenges for the north coast of the state of São Paulo, Brazil. Sustentabilidade em Debate Brasília 2(2): 55-82. ISSN 2179-9067. http://periodicos.unb.br/index. $\mathrm{php} / \mathrm{sust} /$ article/view/5819/4823

McSweeney C, New M, Lizcano G, Xu L (2010) The UNDP climate change country profiles: improving the accessibility of observed and projected climate information for studies of climate change in developing countries. Bull Am Meteorol Soc 91:157-166. doi:10.1175/2009BAMS2826.1

Measham TG, Preston BL, Smith TF, Brooke C, Gorddard R, Withycombe G, Morrison C (2011) Adapting to climate change through local municipal planning: barriers and challenges. Mitig Adapt Strat Glob Change 16(8):889-909. doi:10.1007/s11027011-9301-2

Moser SC, Ekstrom JA (2010) A framework to diagnose barriers to climate change adaptation. Proc Natl Acad Sci USA 107:22026-22031. doi:10.1073/pnas.1007887107

Nelson DR, Adger NW, Brown K (2007) Adaptation to environmental change: contributions of a resilience framework. Annu Rev Environ Resour 32:395-419
PROVIA (2013) PROVIA guidance on assessing vulnerability, impacts and adaptation to climate change. Consultation document, United Nations Environment Programme, Nairobi, Kenya

Runharr H, Mees H, Wardekk A, van der Sluijs J, Driesse PPJ (2012) Adapation to climate change-related risk in Dutch urban areas: stimuli and barriers. Reg Environ Change 12:777-790. doi:10. 1007/s10113-012-0292-7)

Sakai RO, Cartacho DL, Arasaki E, Alfredini P, Pezzoli A, De Sousa WC Jr, Rosso M, Magni L (2013) Extreme events assessment methodology coupling debris flow, flooding and tidal levels in the coastal floodplain of the San Paulo North Coast (Brazil). Int J Geo Sci 4(5B):30-38

Sales RFM Jr (2009) Vulnerability and adaptation of coastal communities to climate variability and sea-level rise: their implications for integrated coastal management in Cavite City, Philippines. Ocean Coast Manag 52:395-404. doi:10.1016/j. ocecoaman.2009.04.007

São Paulo (Estado) (2009) Law n . 13.798. Política Estadual de Mudanças Climáticas-PEMC. http://www.ambiente.sp.gov.br/ pemc/. Accessed 26 Dec 2015

Shaw J, Danese C, Stocker L (2013) Spanning the boundary between climate science and coastal communities: opportunities and challenges. Ocean Coast Manag 86:80-87. doi:10.1016/j.ocecoa man.2012.11.008

Small C, Nicholls RJ (2003) A global analysis of human settlement in coastal zones. J Coast Res 19(584):599

Spence A, Poortinga W, Butler C, Pidgeon N (2011) Perceptions of climate change and willingness to save energy related to flood experience. Nat Clim Change 1:46-49. doi:10.1038/ nclimate 1059

Taylor D, Olwig MF, Chhetri N (2012) Adaptation as innovation, innovation as adaptation: an institutional approach to climate change. Appl Geogr 33:107-111. doi:10.1016/j.apgeog.2011.10. 011

Teixeira LR (2013) Megaprojetos no litoral norte paulista: o papel dos grandes empreendimentos de infraestrutura na transformação regional. Tese Doutorado em Ambiente e Sociedade. NEPAMIFCH, Campinas

Tribbia J, Moser SC (2008) More than information: what coastal managers need to plan for climate change. Environ Sci Policy 11:315-328. doi:10.1016/j.envsci.2008.01.003

Vogel C, Moser SC, Kasperson RE, Dabelko GD (2007) Linking vulnerability, adaptation, and resilience science to practice: pathways, players, and partnerships. Glob Environ Change 17:349-364. doi:10.1016/j.gloenvcha.2007.05.002 